\title{
Neo-Tethyan evolution in southeastern extension of Tibet: Constraints from Early Paleocene to Early Eocene granitic rocks with associated enclaves in Tengchong Block
}

Shao-Wei Zhao*a, Shao-Cong Lai ${ }^{b}$ Xian-Zhi Pei ${ }^{a}$

a School of Earth Science \& Resources, Chang'an University, Key Laboratory of Western Mineral Resources and Geological Engineering Ministry of Education, Xi'an 710054, China b State Key Laboratory of Continental Dynamics, Department of Geology, Northwest University, Xi'an 710069, China CorrespondingE-mail: shwzhaoqx@163.com

The granite is one of most widely distribution rocks in crust, and its petrogenesis is crucial to advance our knowledge of thermal condition in continental crust. The long-time tectonic evolution of crust in the active continental margin could be recorded by multi-stages of granitic assemblage. In order to reveal the subduction of Neo-Tethys and initial collision of Indian-Asian continents in eastern Tibetan Plateau, we selected the Early Paleocene to Early Eocene granitic rocks with associated enclaves in Tengchong Block, southeastern extension of Gangdese magmatic belt, to clarify their different derivation regimes using geochemical and isotopic compositions, mineral compositional variation. The zircon data show that Early Paleocene granites formed at 64Ma, and Early Eocene granitic rocks formed at 54Ma. Combing with the field contact relationship, the similar and enriched $\mathrm{Sr}-\mathrm{Nd}-\mathrm{Pb}$ and zircon Hf isotopic compositions indicate that the two stages of granitic rocks have a common and ancient lower crustal source. The enclaves in Early Paleocene granites could be autolith, representing early crystallization products, but the enclaves in Early Eocene granitic rocks are products of magma mixing between mafic and felsic magma. According to rock assemblages and geochemical signatures of granitic rocks during Early Paleocene to Early Eocene in Tengchong Block, we propose that Early Paleocene granitic rocks are derived from partial melting of lower crustal rocks induced by long-lived heat accumulation with no or minimal basalt flux during the Neo-Tethyan subduction, whereas Early Eocene granitic rocks are derived from melting of crustal materials resulted from high mafic magma flux during Indian-Asian continental collision. The initial collision occurred at ca. $55 \mathrm{Ma}$. Funds: National Natural Science Foundation of China [Grant No 41902046], Natural Science Foundation of Shannxi [Grant No. 2019JQ-682]. 